\title{
A Farewell Tribute to the Antarctic Research Vessel Polar Duke
}

\author{
University of Hawaii • Department of Oceanography • Honolulu, Hawaii 96822 USA
}

n 14 May 1997, the research vessel (R/V) Polar Duke departed Punta Arenas, Chile, bound for Port Fourchon, Louisiana, thus ending a historic 13-year charter to the U.S. National Science Foundation (NSF) as their flagship for science programs in the region of the Antarctic Peninsula (Figure 1, A and B). During this period, the R/V Polar Duke sailed along the coastal waterways, fjords, and open seas that were only first explored less than a century ago. Since January 1985, the R/V Polar Duke logged in excess of 400,000 miles, conducting research on a broad range of topics (Table 1). In addition to her important marine science mission, the R/V Polar Duke also provided year-round logistical support for the science programs conducted at the U.S. research base Palmer Station, for several seasonal field camps and for the U.S. Special Assignment Airlift Missions (SAAM) to King George Island (Figure 1B). In her support capacity, the R/V Polar Duke transported people, equipment, food, construction supplies, and other materials south from Tierra del Fuego, and retrograded all wastes generated south of $60^{\circ}$, as required by the Antarctic Treaty.
Over the years, the R/V Polar Duke has transported, in addition to scientists and support personnel, many dignitaries, ambassadors, journalists, artists, administrators, and others to the ice to both observe and record the diverse science programs conducted in Antarctica. The R/V Polar Duke was also called into emergency medical evacuation service ("medevac") on several occasions, earning her well-deserved reputation as the lifeline of the Antarctic Peninsula. In October 1985, the U.S. Embassy in Santiago, Chile received a request from the Chilean government for assistance in obtaining fuel and supplies that were urgently needed-R/V Polar Duke to the rescue. Later that same season, the $\mathrm{R} / \mathrm{V}$ Polar Duke rescued passengers aboard the British ship RRS John Biscoe, which was beset in pack ice off Adelaide Island. In 1989, she responded to the grounding of the Argentine ship MS Bahia Paraiso off Palmer Station and supported the sampling efforts of a science party deployed to the region to assess the impact of this first major fuel spill in the Southern Ocean (Kennicutt et al., 1990). In 1997, the R/V Polar Duke supported a novel, electronic field trip to the Antarctic Peninsula

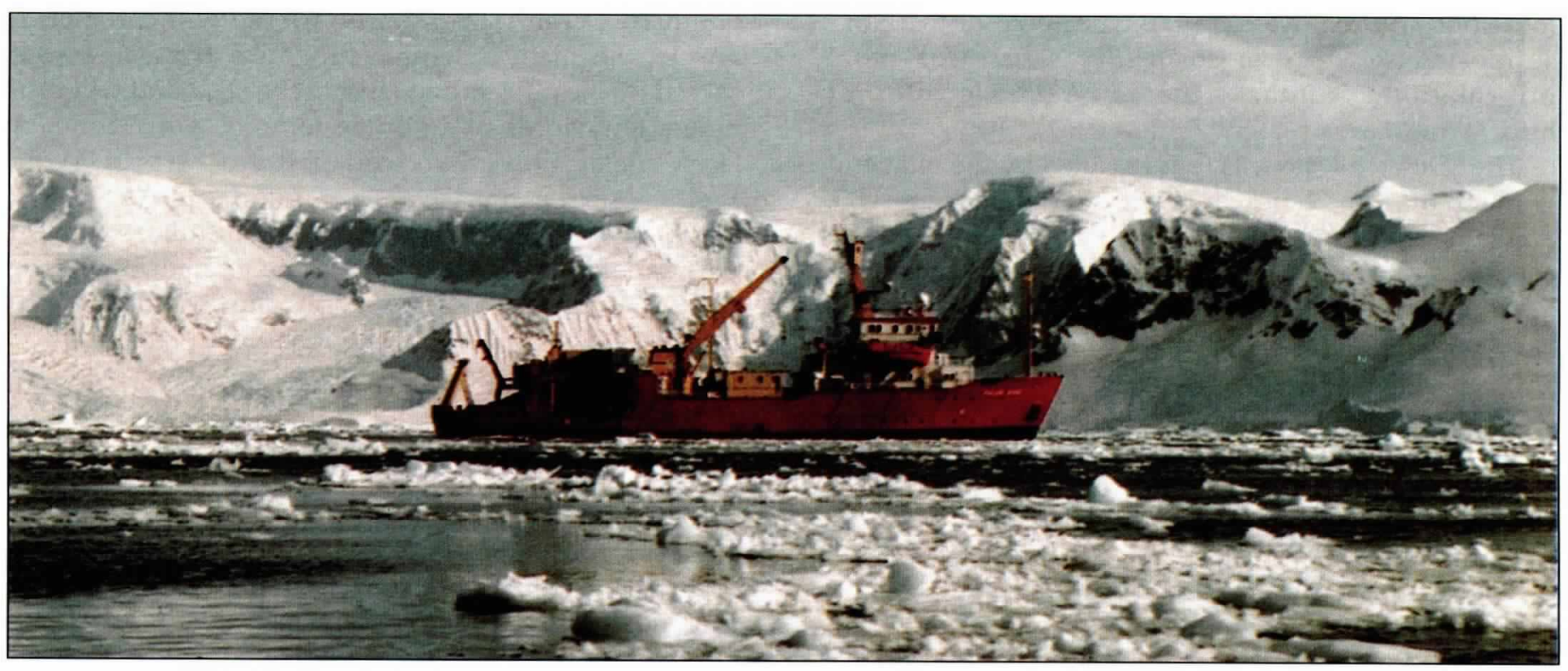

The R/V Polar Duke on one of her many transits through the Gerlache Strait, one of the most spectacular, scenic places on Earth. All photos by author unless otherwise noted. 


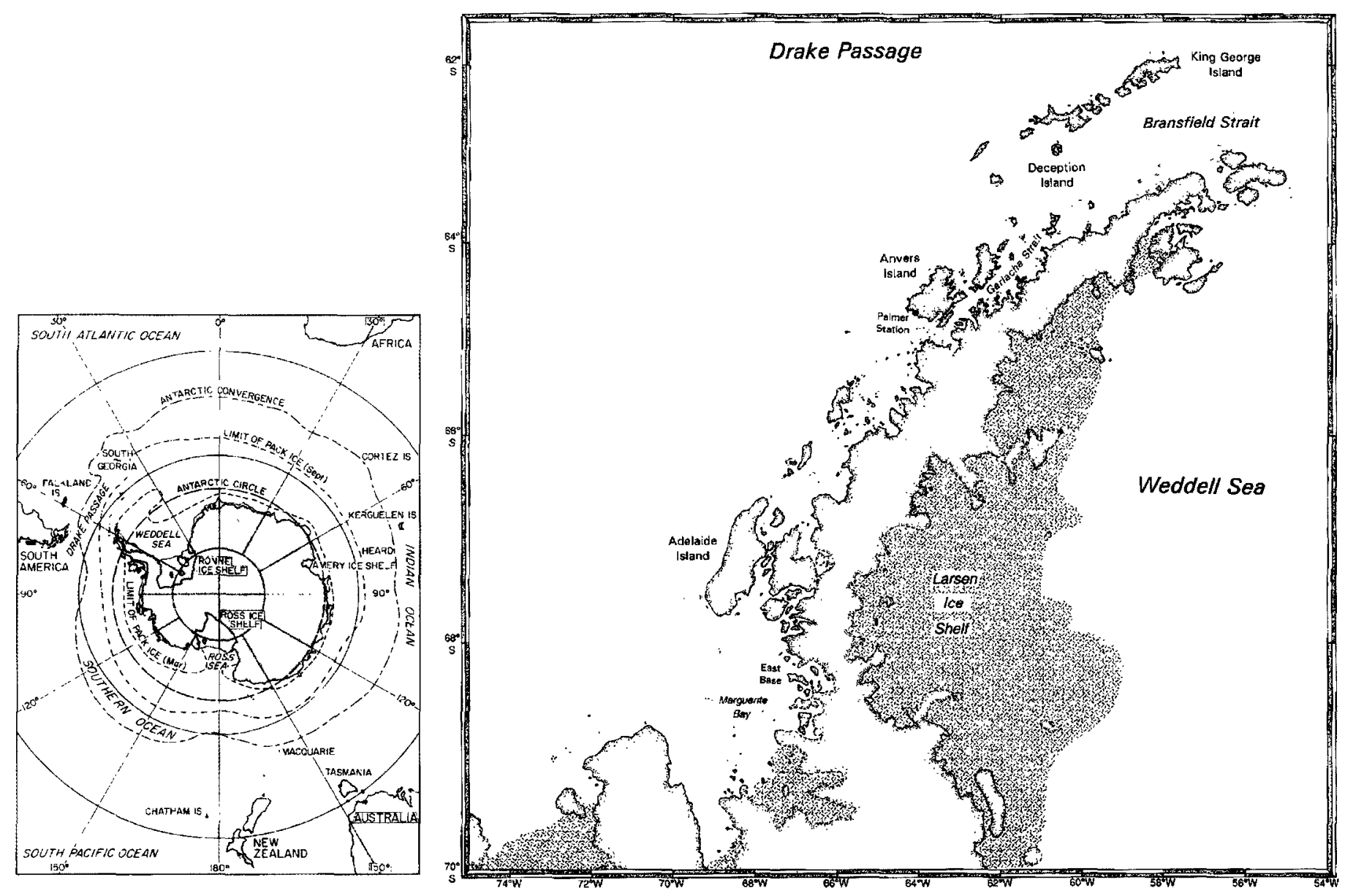

Figure 1: (A) Map of the Antarctic continent showing a few of the major areas of R/V Polar Duke science support over the past 13 years. (B) Enlarged portion of the Antarctic Peninsula commonly known as "Duke's Place."

via interactive television and on-line networks. The "Live From Antarctica 2" broadcasts provided an unprecedented view of life aboard the research vessel and science activities on the ice to students around the world; "real science, real scientists, real locations and real time" in the true spirit of the NSFsupported Passport to Knowledge series (for more information, contact the LFA-2 website at http:/ / quest.arc.nasa.gov/antarctica2).

The "Duke," as she was fondly called by the men and women of the National Science Foundation's U.S. Antarctic Program (USAP), will be remembered as a capable and comfortable vessel with an extremely professional, "user-friendly" crew. This commitment to excellence, combined with the expert science support services provided by the USAP contractors ITT Antarctic Services (1985-1990) and Antarctic Support Associates (1991-1997) and their capable Chilean maritime port servicing agents (COMAPA and AGUN$\mathrm{SA}$ ) is the main reason why many oceanographers rate the R/V Polar Duke a truly exceptional research vessel. Her legacy of scientific achievement is remarkable, in part, because of the unique opportunities and challenges that arose during the period of her service, especially with issues related to global environmental change. She has transported ice and sediment cores that chronicle the history of earth's climate, petrified wood and animal fossils that support the theory of continental drift, and modern day biological specimens that are providing important clues to the nature of life in the Southern Ocean. This farewell tribute will chronicle a few of the many scientific programs that were well served by the officers and crew of the Duke and will provide a few words of gratitude for a job well done. A "R/V Polar Duke Farewell Tribute" World Wide Web site has also been established (http://hahana.soest.hawaii.edu/polarduke), and all who sailed aboard her are welcome to contribute their photos, accolades, and sea stories directly to the webmaster (see web page for additional instructions).

\section{History of U.S. Science Mission in the Antarctic Peninsula}

U.S. interests in the Antarctic Peninsula date back to the early portion of the 19th century and to the discovery of the Antarctic continent itself. Before achieving its present status as a continent for international scientific discovery, Antarctica was the domain of whalers, sealers, and explorers. The name "Antarctica" is derived 
from the Greek Antarktos-literally translated meaning opposite Arktos, the constellation in the northern sky. As early as 150 A.D., Antarctica appeared on Ptolemy's world map despite objections by "flat earth" orthodoxy and other theological views of that period. High latitude Southern Ocean expeditions led by Ferdinand Magellan (1519-1522) and Francis Drake (1577-1580), and the circumnavigation of the Antarctic continent by Captain James Cook (1772-1774) all failed to sight the Antarctic continent. In 1820, a 19-year-old New England sealer, Nathaniel Palmer, sailed to the Peninsula region aboard his $14-\mathrm{m}$ sloop, Hero. Although there is some debate on this point, he and his fiveman crew may have been the first to see the Antarctic continent after more than three centuries of serious exploration (note: the British Captains William Smith and Edward Bransfield, and the Estonian Captain Thaddeus Bellingshausen have also been so credited).

It was nearly 75 years before any comprehensive scientific expeditions were conducted in the Antarctic Peninsula region. Among the first were the Belgian Antarctic expedition in 1897 headed by Adrien deGerlache, which included Henryk Arctowski and Roald Amundsen as members of the party, the Scottish National Antarctic Expedition (1902-1904) in the Weddell Sea headed by William Bruce, and several French expeditions headed by Jean Charcot. The U.S. Antarctic Service Expedition in 1939-1941 established a "permanent" base (East Base) on Stonington Island in Marguerite Bay during Admiral Richard Byrd's third Antarctic expedition (Figure IB). This was the first permanent U.S. base on the Antarctic Peninsula. From this location in 1947-1948, the famed explorer Captain Finn Ronne conducted a remarkable 84-day sledge journey to Alexander Island (Lipps, 1976). East Base also became famous as the site where the first women wintered in Antarctica (Mrs. Ronne and Mrs. Darlington), and one left the ice pregnant (Lipps, 1976). The U.S. Operation Highjump (1946-1947), including 4,700 men, 33 aircraft, and 13 ships, marked the beginning of modern scientific research in Antarctica. This post-war assault on the continent focused on terrestrial, not marine, activities. The declaration of the Third International Geophysical Year (IGY; July 1957 to December 1958), organized to coincide with peak sunspot activity, facilitated the first coordinated, interdisciplinary studies of the southern continent. Twelve countries established 40 bases, including the U.S. Amundsen-Scott South Pole Station. Dr. Laurence M. Gould headed the U.S. IGY delegation. The IGY stimulated the creation of the Antarctic Treaty, which was approved by representatives of the 12 IGY partner nations in 1959. This treaty established the legal precedent and protocol for international scientific cooperation south of $60^{\circ} \mathrm{S}$.
In 1963, the United States established an atmospheric research station called Eights Station (named after James Eights, the first American scientist to work in Antarctica) at the base of the Antarctic Peninsula near $78^{\circ} \mathrm{W}, 78^{\circ} 18^{\prime} \mathrm{S}$ (Jones, 1964). During that same field season, a broad reconnaissance was conducted in the Peninsula region for locations to site additional research bases. From an examination of 30 potential sites, Arthur Harbor on the southwestern coast of Anvers Island emerged as the most desirable location (Jones, 1964), and in 1965, a small prefabricated wooden structure was erected at Norsel Point on Anvers Island (Figure 1B), near the site of the abandoned British Antarctic Survey's Base "N" that was established there during the IGY. Thus began a major U.S. presence in the Antarctic Peninsula. Three years later, U.S. science activities in the Peninsula were transferred to the present Palmer Station, which was constructed a few kilometers away from "Old Palmer."

In March 1968, the R/V Hero was launched in South Bristol, Maine to serve as a support vessel for U.S. research activities in the Antarctic Peninsula. The $\mathrm{R} / \mathrm{V}$ Hero $(38 \mathrm{~m}, 300 \mathrm{LT}$ displacement) had a ketch-rigged, diesel-powered trawler-type design and was framed with native oak timbers. Her masts and interior work were of Oregon fir, and her sides were reinforced with Guayanan greenheart for added hardness and durability; she had accommodations for six scientists (Anonymous, 1968). The R/V Hero arrived at Palmer Station on Christmas day, 1968 and served the U.S. Antarctic program with great distinction for nearly two decades. Although the R/V Hero was able to conduct a modest level of oceanographic research, conditions aboard her were less than ideal, especially considering the generally inclement weather in the Southern Ocean. Consequently, until the R/V Polar Duke was brought into service, the Peninsula-based research programs were largely centered at Palmer Station, where scientists had access to a variety of seabird rookeries, intertidal/subtidal marine habitats and, most importantly, laboratories and support personnel.

\section{The Duke Charter}

The R/V Polar Duke was christened in 1983 at Yard No. 55 (VaagenVerft A/S) in Kyrksøterora, Norway (Figure 2). The vessel was initially designed and constructed for service in north polar seas as part of a fleet of research and supply vessels that were owned and operated by Rieber Shipping A/S of Bergen, Norway. As North Sea oil exploration waned, Rieber considered alternative uses for their fleet of ice-strengthened vessels, and in 1984 NSF approved charter of the R/V Polar Duke $(67 \mathrm{~m}, 1600 \mathrm{LT}$ displacement) as a replacement for the R/V Hero, which was being retired after nearly 20 years of Antarctic service. 
At the time of the initial 3-year charter agreement in 1985, the Duke was operated by Carino Shipping Ltd., St. John's, Newfoundland (CAnada-RIeber-NOrway, a wholly-owned subsidiary of Rieber Shipping A/S), and sailed under a Canadian flag with a predominantly Canadian crew. In 1989, the vessel was reflagged Norwegian international, and from that point on she sailed largely with a Norwegian crew supplemented with Chilean cooks, messmen, oilers and able-bodied seamen. In the shadows of Nansen, Amundsen, Larsen, and other famous Norwegian explorers, the officers and crew of the $\mathrm{R} / \mathrm{V}$ Polar Duke have distinguished. themselves over the years by dedication and determination in pursuit of their science support mission.

The initial charter requirement was for the R/V Polar Duke to perform austral summer research and resupply tasks similar to those assigned previously to the $\mathrm{R} / \mathrm{V}$ Hero. Her first season-three cruises between Punta Arenas, Chile, and the Antarctic Peninsula from January to April 1985-conformed to this minimal expectation. However, by the end of her first year, the capabilities of the R/V Polar Duke were challenged by a rare winter

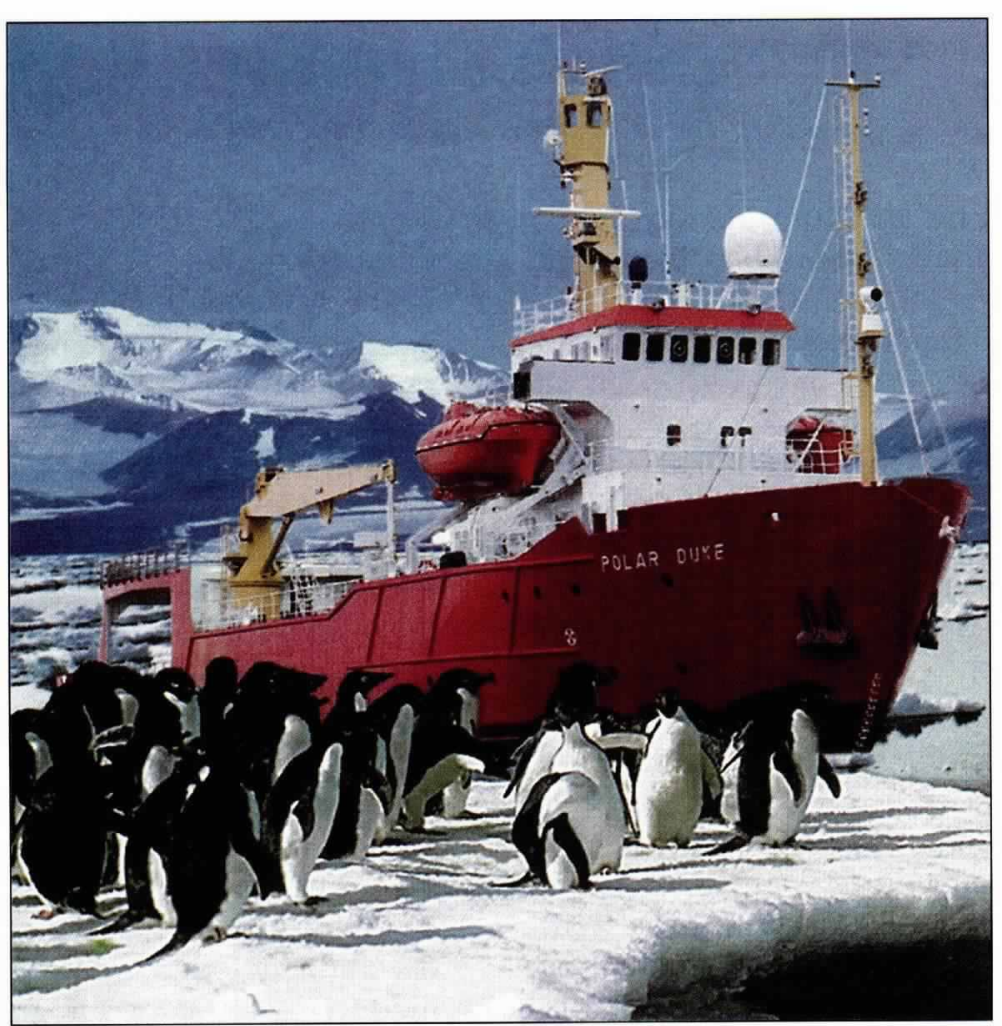

Figure 2: The $R / V$ Polar Duke is an ice-strengthened vessel with accommodations for 26 scientists. Diesel propulsion and thrusters fore and aft provide excellent maneuverability and station keeping. Photo by Reiber Shipping A/S.
Despite the loss of the Duke from the USAP program, Antarctic scientists have reason to be optimistic about the future. A new ice-strengthened research vessel (class ABS A-1), Laurence M. Gould (71m, 3400 LT displacement), has replaced the Duke for an initial five-year charter in December 1997. The R/V Laurence M. Gould is operated by Edison Chouest Offshore, Galliano, Louisiana for the USAP under a subcontract with Antarctic Support Associates. Those sometimes exotic Norwegian entrees and vintage Chilean Cabernets (limited to $3 \mathrm{oz}$. per dinner meal) have given way to red beans, rice, and Coca Cola as the scientists in the U.S. Antarctic Program moved from the Rieber to the Chouest vessel charter agreement.

\section{The Drake Passage}

According to the Antarctic Pilot, "navigation in the Southern Ocean is rendered difficult by sea ice, sudden violent and unpredictable changes in weather, an unusually high proportion of dangerous shoals rising precipitously from deep water, large seas and swells, instability of the compass at high latitudes, inadequate charts and lack of navigational aids." It goes on to state the obvious, "The mariner should exercise great care when navigating in these waters." Despite all safety precautions that are routinely taken, work in Antarctica is still very hazardous. The R/V Polar Duke and the entire U.S. Antarctic Program pride themselves on their excellent safety records to date.

A major obstacle, if not impediment, for science operations in the Peninsula region of Antarctica is the Drake Passage. This malevolent portion of the global ocean, located between Cape Horn to the north and the South Shetland Islands to the south (Figure 1, A and B) is, without a doubt, one of the most inhospitable places on Earth. Although on rare occasion the Drake Passage is sunny and calm, it usually is quite the opposite. Storms move in a more or less continuous succession from west to east at a latitude of approximately $60^{\circ} \mathrm{S}$ in the Pacific sector of the Southern Ocean. Overcast sky and low barometric pressures $(<985 \mathrm{mb})$ are possible; gales are common. The waves produced in Drake Passage, called 
Cape Horn rollers, are legendary. They can achieve lengths of $>1 \mathrm{nmi}$, crest to crest, and reach heights of 25 m (Lansing, 1959). As Charles Darwin wrote on first observing the Drake's fury in 1833, "The sight is enough to make a landsman dream for a week about death, peril and shipwreck," or as Patricio Rojas, a cook aboard the R/V Polar Duke, recently proclaimed in a press release on Wild Antarctica, "The Drake Passage makes the living wish they were dead, and makes an atheist believe in God!" Every time I make the crossing I think about Shackleton and his men who made a forced crossing of the Drake Passage from Elephant Island to South Georgia in their open, $6 \mathrm{~m}$ dory, James Caird. That helps to place my own misery into a broader and more realistic perspective.

\section{Selected Scientific Benchmarks}

It is impossible to review or even mention all of the scientific accomplishments of the many investigators who have conducted research aboard the R/V Polar Duke during her 13 years of service. Interested readers are encouraged to consult the annual review issues of the A $n \mathrm{t}$ a $\mathrm{C} \mathrm{t}$ i c Journal of the United States for summaries of the results of these diverse field programs (see Table 1 for a few examples). There are, however, at least two areas of research that deserve mention not only because of their significance, but also because of their much broader implications to earth and ocean sciences. These

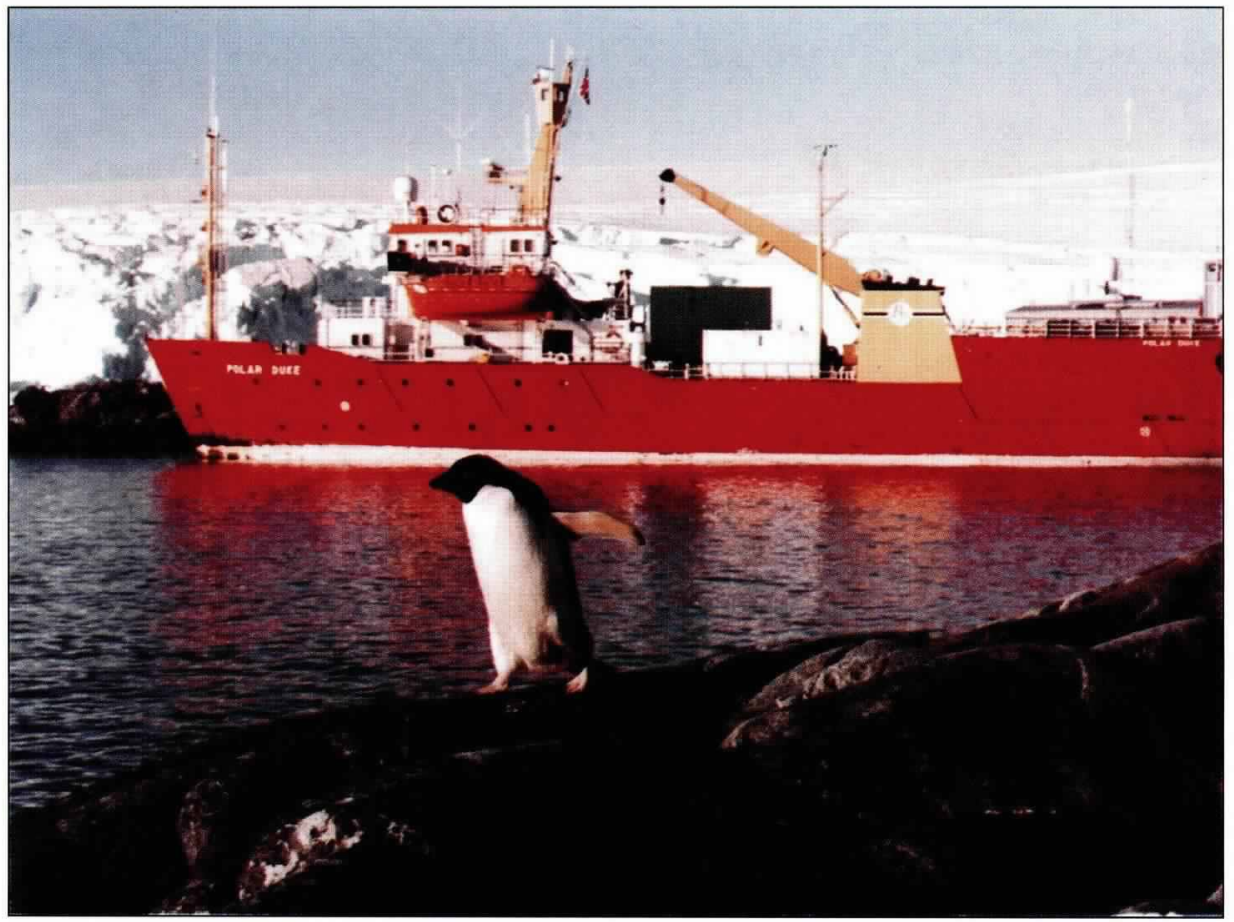

$R / V$ Polar Duke calls at Palmer Station $\left(64^{\circ} 46^{\prime} S, 64^{\circ} 03^{\prime} W\right)$, the U.S. research base in the Antarctic Peninsula. Established in 1968, this station now supports a diverse range of science projects from marine biology to meteorology and upper atmosphere studies. It is also the site of several large penguin rookeries and, since 1991, the site of a NSF Long Term Ecological Research (LTER) project. topics include 1)

Antarctic stratospheric ozone depletion, increased surface ultraviolet solar irradiance, and effects on ecosystem processes; and 2) biogeochemical processes, carbon fluxes, and the structure and function of Antarctic food webs. Both of these broad research topics have been studied extensively by investigators working aboard the R/V Polar Duke since 1985.

\section{Occurrence and Consequence of the Ozone Hole}

Ozone, a triatomic form of oxygen $\left(\mathrm{O}_{3}\right)$, occurs naturally in the earth's stratosphere and elsewhere. Ozone is both an important oxidant and a precursor for other reactive compounds, and plays a crucial role in atmospheric photochemistry (Molina and Rowland, 1974; Schnell et al., 1991). Ozone is essential for life on earth; it absorbs both infrared and UV-B $(280-320 \mathrm{~nm})$ radiation and, consequently, helps to drive the global circulation of the upper atmosphere. The amount of ozone at any one location on earth is called the "total ozone column" and is expressed as the height of $\mathrm{O}_{3}$ at standard temperature and pressure measured in $10^{-5} \mathrm{~m}$, or Dobson units (DU). The amount of $\mathrm{O}_{3}$, present at any given time and place is a complex balance between numerous sources, sinks, and transport processes. Geographical, seasonal, and interannual variations in $\mathrm{O}_{3}$ are both expected and observed.

Superimposed on these natural $\mathrm{O}_{3}$ dynamics is the discovery, by Farman and co-workers, of the episodic loss of $\mathrm{O}_{3}$ each austral summer over Antarctica (Farman et al., 1985; Solomon et al., 1986). This loss of stratospheric $\mathrm{O}_{3}$, the so-called "ozone hole," is attributed to $\mathrm{O}_{3}$ destruction by chlorine radicals via chemical catalysis. These reaction mechanisms were first described by $M$. Molina and F.S. Rowland in 1974, research for which they later were awarded the 1995 Nobel $\mathrm{P} r$ i $z$ e i $n$ C h e m is t r y along with $P$. Crutzen, another ozone chemistry pioneer. These natural $\mathrm{O}_{3}$-destroying reactions are now known to be stimulated by release into the atmosphere of manmade chlorofluorocarbons (CFCs), thereby providing a compelling case study for our direct intervention on earth's climate.

During the annual development of the Antarctic 


\section{TABLE 1}

Selected research programs supported by the R/V Polar Duke during her service to the U.S. National Science Foundation's Antarctic Program (1985-1997)

Project Title

Marine Geology \& Geophysics

Marine heat flow

Paleoclimate history of southern Chile

Stratigraphy in Antarctic fjords

Marine geology of Antarctic continental margins

Marine Chemistry

Particulate matter flux

Cycling of biogenic silica

Iron and phytoplankton production

Physiological ecology of ultraviolet absorbing compounds

Hydrocarbons in the Antarctic Peninsula region

Marine Biology

Antifreeze proteins in Antarctic fishes

Energetics of Antarctic krill

Physiology of ice algae

Behavioral ecology of Weddell seals

Microbial chitin degradation

Life history of Antarctic fishes

Biology of gelatinous zooplankton

Meteorology/Oceanography

Marine sources of sulfate aerosol

Network for monitoring ultraviolet radiation

Photochemistry of Antarctic waters

Ozone depletion and phytoplankton biology

Cloud condensation nuclei: a link between ocean-sulfate and climate

Oceanography

Trophic coupling between mesopelagic and sea-ice communities

Long-term ecological research on the Antarctic marine ecosystem

Research on Antarctic coastal ecosystem rates

Hydrothermal vents in the Bransfield Straits

Formation of Antarctic bottom water

Ecology of marine Antarctic archebacteria
Principal Investigator

L. Lawver

A. Leventer

E. Domack

J.B. Anderson

R. Dunbar

D. Nelson, D. Demaster

J.H. Martin

D. Karentz

M. Kennicutt
A. DeVries
R. Ross, L. Quetin
C. Sullivan
J.W. Testa
J.T. Staley
R. Radtke
R. Harbison
H. Berresheim
C.R. Booth
K. Mopper, D. Kieber
R. Smith, B. Prézelin
V. Saxena
K. Smith
R. Ross/R. Smith and others
M. Huntley and others
G. Klinkhammer
T. Foster
E. DeLong

ozone hole, there can be complete loss of $\mathrm{O}_{3}$ in the lower stratosphere and up to $50 \%$ loss of total column $\mathrm{O}_{3}$, (from typical winter values of $300 \mathrm{DU}$ to springtime minima of $150 \mathrm{DU}$ ) during a period of less than six weeks generally beginning in late August. The size of the Antarctic ozone hole has been increasing since the early 1980s (Jiang et al., 1996), and this has stimulated research into this important area.

Changes in total column $\mathrm{O}_{3}$ concentrations have direct effects on UV-B irradiance at the earth's surface and, hence, implications for UV-B dependent photochemistry and photobiology. Ozone selectively absorbs UV-B and does not alter visible light (400-700 nm); consequently, $\mathrm{O}$ depletion selectively increases UV-B fluxes. A major body of literature exists on the effects of UV-B radiation on the physiology and growth of a vari- ety of marine organisms (Voytek, 1990; Häder and Worrest, 1991), but less is known about the ecological consequences. An authoritative review of present knowledge has recently appeared (Karentz et al., 1994). In response to a recognized need to obtain more information on the potential ecological impacts of the Antarctic ozone hole, a ground-based scanning spectroradiometer (280-700 $\mathrm{nm}$ with $0.75 \mathrm{~nm}$ bandwidth) was deployed at Palmer Station in May 1988 as part of the USAP UV monitoring network to measure the ozone hole in the Peninsula region (Booth et al., 1994). With the aid of this instrument, Frederick and Lubin (1994) were able to document a springtime period of enhanced solar UV irradiance at Palmer Station that coincided with the atmospheric ozone depletion. At the same time, several important studies were initiated aboard 
the R/V Polar Duke, and at Palmer Station, the results of which have provided new insights into this complex and important environmental problem.

Holm-Hansen et al. (1989) were among the first to recognize the importance of UV-B radiation on rates of photosynthesis in Antarctic marine phytoplankton. Subsequent field studies further documented a significant UV radiation (both UV-A and UV-B) inhibition on the rate of phytoplankton growth (Helbling et al., 1992, 1994). On sunny days when total UV radiation was high (>10-15 $\left.\mathrm{W} \mathrm{m}^{-2}\right)$, photosynthesis was increased $200-300^{\circ} \%$ by the removal of all UV light (<378 nm) using selective filters. However, when the total UV radiation was lower $\left(<10 \mathrm{~W} \mathrm{~m}^{-2}\right)$, more typical of partly cloudy days, no effect was observed. They also reported that UV radiation was more inhibitory to microplankton (primarily diatoms) than to nanoplankton (primarily flagellates), a result that may have implications for food web dynamics especially considering the important role of microplankton as a food source for Antarctic krill and other large herbivores (Helbling et al., 1994). Because UV-B radiation is rapidly absorbed in the upper $10-20 \mathrm{~m}$ of the water column, depending on the amount of dissolved organic matter and other properties, the effective dose of UV radiation is difficult to determine unless relevant complementary measurements (e.g., ocean mixing rates) are made at the same time. According to Bidigare (1989), a quantitative assessment of the effects of UV-B enhancement will require knowledge of 1 ) the wavelength-dependent flux of UV-B in the ocean, 2) action spectra for UV$B$ damage to Antarctic organisms, and 3) depth-dependent distributions and residence times of organisms in the mixed layer.

Based on the results of their "Icecolors-90" cruise in the Bellingshausen Sea aboard the R/V Polar Duke (October to November 1990), Smith et al. (1992) reported that the Antarctic ozone hole has resulted in shifts of in-water spectral irradiances that had affected Antarctic marine ecosystem processes including a minimum $6-12 \%$ reduction in primary production during the period of their observations. However, because the maximum in enhanced UV-B radiation occurs at a time of the year (early spring) when phytoplankton production rates are relatively low, the impact on total annual organic matter production may be negligible (HolmHansen et al., 1993). The comprehensive field study of Smith et al. (1991) examined not only the short-term effects of increased UV-B radiation, but also the equally important photoregulatory ecological processes, including UV-A and UV-B induced photoprotective mechanisms (see also Prézelin et al., 1994). Among the most effective photoprotectant organic compounds discovered were the mycosporine-like amino acids. A field survey of a variety of marine algae and higher organisms, also conducted aboard the R/V Polar Duke and at Palmer Station, demonstrated a widespread occurrence of these natural sunscreens (Karentz et al., 1991). A more recent comparison of the effects of UV radiation on phytoplankton derived from short-term (1 day) versus long-term (2 weeks) incubations revealed that cells can acclimatize and adapt to increased UV fluxes (Villafañe et al., 1995). Consequently, the long-term ecological impacts may be less than initially believed. Clearly more studies are warranted before any predictive ecosystem models can be developed.

In addition to these studies on the effects of UV-B radiation on phytoplankton, recent investigations aboard the R/V Polar Duke have documented other potentially important impacts on a variety of populations and processes. Bacteria, the primary consumers of dissolved organic matter in marine ecosystems, are known to be susceptible to UV radiation, and Southern Ocean bacteria are no exception. Field studies conducted during the R/V Polar Duke-supported DIMERS expedition (Damage In Microorganisms from Environmental Radiation in the Southern Ocean; W. Jeffrey, Chief Scientist) have documented a significant inhibition of heterotrophic growth and metabolism and measured production of UV-induced photoproducts in bacteria under the Antarctic ozone hole. Another effect on bacterial population dynamics may be via the interactions of UV radiation and infectious viruses. Because they lack DNA repair mechanisms, viruses may be especially susceptible to ozone hole enhancements in UV-B radiation. To the extent that virus infection is a major control on plankton populations, changes in their infectivity rates could influence ecosystem dynamics and carbon fluxes. The decreased abundances of virus particles observed in the surface waters of the Antarctic Peninsula (Bird et al., 1993) are consistent with this model.

Malloy et al. (1997) have recently presented the first direct evidence that increased UV-B radiation may damage the DNA of higher organisms within a natural population of Antarctic zooplankton. Studies conducted aboard the R/V Polar Duke demonstrated that the eggs of the Antarctic icefish are susceptible to ozoneinduced UV-B radiation increases resulting in DNA damage, identical to that observed in microorganisms. Consequently, enhanced UV-B fluxes may affect recruitment as well as transfer of organic matter to higher trophic levels. Finally, the increased levels of UV-B radiation in Antarctic waters may also significantly magnify the rates of euphotic zone photochemical processes (in addition to DNA dimerization), which, in turn, may have either negative or positive effects on the associat- 
ed populations. One interesting but unpredictable effect is the partial photolysis of otherwise refractory dissolved organic matter to produce labile, low molecular weight substances such as pyruvate (Kieber, 1994). The formation of these labile precursors could, in turn, stimulate heterotrophic bacterial production in these reduced carbon-limited waters, and potentially, decouple photoautotrophic and chemoheterotrophic processes. This coupled photochemical-bacterial processing of this large In 1989, the R/V Polar Duke supported field research conducted by personnel from John Martin's laboratory

to evaluate the hypothesis that trace metals, specifically iron, control primary production

in Antarctic ecosystems. flow through microheterotroph (bacterial) and protozooplankton (flagellate and ciliate) assemblages. In fact, we can expect our views on the structural complexity of the Antarctic food web to expand further as we incorporate new ecosystem processes currently under investigation. The concept of a highly efficient and simple Antarctic marine food chain is no longer tenable, but comprehensive, quantitative studies of energy and carbon flow through the entire Antarctic food web still do not exist. This information is crucial reservoir of organic matter could have a major effect on both carbon and oxygen cycles in Antarctic surface waters (Karl and Resing, 1993).

\section{Antarctica's Role in Global Ecosystem Dynamics and Global Biogeochemical Cycles}

The Antarctic marine ecosystem-the assemblage of plants, animals, microbes, sea ice, ocean and land margins south of the Antarctic Convergence Zone-is one of the largest readily identifiable biomes on Earth (Hedgpeth, 1977). The Southern Ocean is an important site for deep ocean ventilation and bottom water formation and for the exchange of gases and heat between the ocean and atmosphere and is the major surface ocean repository of unused plant nutrients. It is also one of the most poorly understood habitats, especially in terms of ecosystem rates and processes, and physical controls thereof. For example, before 1980, energy flow in Antarctic marine habitats was believed to be adequately modeled by a relatively short and therefore highly efficient transfer from large phytoplankton cells $(>35 \mu \mathrm{m})$ to krill to higher trophic levels (e.g., whales, seals, and birds). More recently, this classical, linear view of the Antarctic food chain has been expanded to reflect the roles of other herbivorous and carnivorous macrozooplankton, benthic secondary productivity and plankton-benthos coupling, and energy for understanding the structure and efficiency of the "biological pump" in order to assess the role of the Southern Ocean in global atmospheric carbon dioxide regulation and other ecosystem processes.

Recently there has been renewed interest in the control of organic matter production in regions of high nutrients and low chlorophyll that characterize much of the Southern Ocean. In 1989, the R/V Polar Duke supported field research conducted by personnel from John Martin's laboratory to evaluate the hypothesis that trace metals, specifically iron, control primary production in Antarctic ecosystems. This research has major implications to both paleo- and modern environments and may help to explain contemporary levels of atmospheric carbon dioxide (Martin et al., 1990). Martin's research aboard the R/V Polar Duke revolutionized our conceptual views of bioge ochemical cycling of carbon in the Southern Ocean that culminated in a provocative and forward-looking symposium on the topic (Chisholm and Morel, 1991) and many additional field studies.

One unique attribute of Southern Ocean ecosystems is the extreme temporal variability in climate including, but not limited to, variations in solar radiation and seaice extent. Repeat observations over several years and during all seasons, and comprehensive synoptic assessments of ocean circulation, chemistry, and biology will 
be required to elucidate ecosystem structure and function and, ultimately, to determine the role of the Southern Ocean in global biogeochemical cycles.

During the past decade, three largescale, transdisciplinary research programs have invested substantial intellectual and financia 1 resources in an attempt to gain a better understanding of the Southern Ocean ecosystem. These studies include the 1) Antarctic Marine Ecosystem Research at the Ice-Edge Zone (AMERIEZ) program, 2) Research on Antarctic

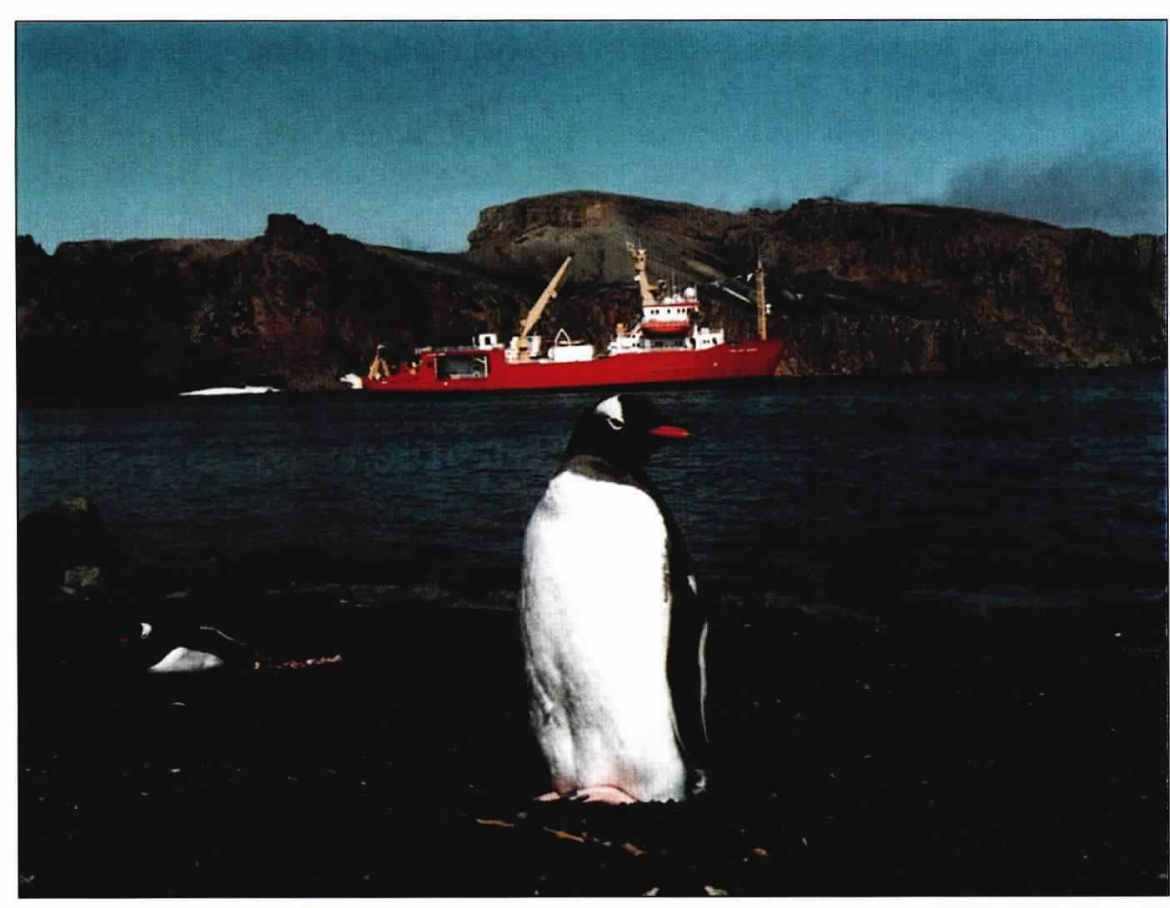

The R/V Polar Duke at quiet anchor in Port Foster, Deception Island. This island, of volcanic origin, has played an important role in the history of Antarctic exploration and research. dicular to the ice-edge margin and extending 100-250 $\mathrm{km}$ south into the pack ice and $>200 \mathrm{~km}$ north into the open regions of the WeddellScotia Sea. Hydrographic observations generally support the previous model of $\mathrm{me} 1 \mathrm{t} w$ a $\mathrm{t}$ e $\mathrm{r}$ induced stratification of the water column as an important factor responsible for the accumulation of phytoplankton biomass near the ice edge, especially during austral spring. The Duke$\mathrm{s}$ u p p o r t e d AMERIEZ cruise was by far the most ambitious and complete ecosystem investigation ever Coastal Ecosystem and Rates (RACER) program, and 3) Palmer Long-Term Ecological Research (Palmer LTER) program. All three of these large ocean-going investigations of pelagic marine ecosystem dynamics and biogeochemical processes have benefitted from the excellent support capabilities of the R/V Polar Duke and from the collective expertise of her officers and crew. These field programs will stand as one portion of the Duke legacy.

AMERIEZ. This multidisciplinary investigation of pelagic ecosystem structure and processes was designed to build upon previous research at the marginal sea-ice zone (Sullivan and Ainley, 1987; Smith and Garrison, 1990). Its two unifying hypotheses were 1) that the pack-ice edge is a major oceanographic feature characterized by increased biomass and biological productivity and 2) that the seasonal advance and retreat of the ice margin, which represents an ecological interface between two communities, strongly affects the natural history of most organisms in the vicinity. These general hypotheses, and ecological predictions thereof, were systematically evaluated during three comprehensive research expeditions to the marginal ice-edge zone of the Weddell Sea during austral spring (10 November to 2 December 1983), austral autumn (7-27 March 1986), and austral winter (9 June to 13 August 1988). The 1988 winter cruise was conducted aboard the R/V Polar Duke (Ainley and Sullivan, 1989).

The experimental design consisted of a sampling grid of discrete stations running more or less perpen- before, or since, attempted in austral winter. Of great significance was the documentation of active populations of predators despite very low phytoplankton biomass and low rates of primary production (Ainley and Sullivan, 1989). This apparent temporal decoupling in population dynamics emphasizes the importance of year-round observations of ecosystem processes in high latitude habitats. Hallmarks of the AMERIEZ program have been its truly interdisciplinary approach and its strong component on microplankton rate processes. Another unique aspect has been the incorporation of satellite remote-sensing imagery to define the mesoscale variability and dynamics of the ice-edge zone in the area of interest (Comiso and Sullivan, 1986; Sullivan et al., 1988). Although the AMERIEZ program participants compiled the most comprehensive ice-edge database available to date, the experimental design is still open to criticism on the basis of their use of multiyear data to infer a seasonal cycle. This ignores the importance of well-documented interannual variability and uncertainties in the interpretation of synoptic primary and secondary production rate measurements without complementary information on antecedent or subsequent ecosystem processes (e.g., successional events). Unfortunately, without a more complete time series including observations of particle flux, quantitative assessment of seasonal carbon and energy flow is still beyond the scope of even this most comprehensive study. 
RACER. In 1981, the Committee to Evaluate Antarctic Marine Ecosystem Research (Steele, 1981) identified the coastal zone of the Antarctic Peninsula as one of several Antarctic marine ecosystems needing comprehensive, interdisciplinary study. The coastal shelf region is thought to be especially important because it supports an extensive spring bloom of phytoplankton, has a high annual rate of primary production, and is a principal breeding, feeding, and spawning ground for Antarctic krill. However, the processes responsible for the biological richness of this ecosystem were not well understood, and comprehensive data on microbial rates and element cycling (especially the role of microheterotrophs) in this region are relatively few.

During 1986-1987, an interdisciplinary group of scientists conducted a comprehensive four month field study of 69 stations within a sampling grid of high spatial resolution. The $25,000-\mathrm{km}^{2}$ RACER study area was small in comparison with the entire Antarctic Peninsula coastal region, but contained several representative habitats, including 1) two shelf environments (Antarctic Peninsula and South Shetland Islands) considered to be key habitats for adult and larval krill, 2) two distinct deep-water zones (the western basin of the Bransfield Strait and the shelf-break region of the southern Drake Passage), 3) the frontal zone, or meander, between the Bellingshausen Sea and the Bransfield

Strait water masses, and 4) the eutrophic coastal regions of the northern Gerlache Strait.

The two central hypotheses of the RACER program were the "stability-productivity hypothesis," which stated that upper-ocean physical dynamics control productivity at all levels of the food web and that productivity is significantly greater in nearshore stratified waters than in offshore regions, and the "island effect-residence time hypothesis," which stated that islands and irregular bottom topography interrupt the flow of waters onto the coastal shelf, increasing mean residence time and allowing for greater productivity there than in offshore regions (Huntley et al., 1991). To address these general hypotheses and their ecological predictions, the RACER program combined studies of upper-ocean physics, photobiology and biooptics, microbiology, particle flux, and the distribution and physiological rates of krill, zooplankton, and nekton.

The RACER-I program (1986-1987) was a great success (see Karl, 1991) and was followed by two additional summer expeditions in 1989 and 1991 (RACER-II and -III) aboard the R/V Polar Duke, and, a winter study in July to August 1992 (RACER-IV) aboard the RVIB Nathaniel B. Palmer. During RACER-II, an ARGOSlinked meteorological station was established on RACER Rock, near Lobodon Island in Gerlache Strait, the first of its kind in the Antarctic Peninsula. The combined field results from AMERIEZ and RACER provid- ed ample justification and the incentive to develop a long-term measurement capability to resolve the important seasonal and interannual variations that were observed in ecosystem rates and processes in the Southern Ocean.

Palmer LTER. In 1981, the NSF created the Long-Term Ecological Research (LTER) network as a coordinated program to investigate long-term (>10 yr) ecological phenomena in a variety of habitats. In 1990, the Palmer LTER site was added to this network as a multidisciplinary program to study polar marine ecosystem rates and processes. The central theme of the Palmer LTER program is that the annual advance and retreat of sea-ice is a major physical determinant of spatial and temporal ecosystem productivity and variability, from microbial productivity to the breeding success of apex predators (Smith et al., 1995). The primary objective of this multiinvestigator program is to characterize and understand linkages between the various physical, chemical, and biological components of the Antarctic marine ecosystem and to develop models that accurately reflect and predict these complex ecological interactions.

The Palmer LTER study area is along the western coast of the Antarctic Peninsula from Bransfield Strait in the north to Marguerite Bay in the south, and extending $200 \mathrm{~km}$ seaward from the coast (Figure 1B). The scientific rationale and foundations for the development of this long-term study have been summarized elsewhere (Ross et al., 1996). Because the Palmer LTER study area is situated in a climatically sensitive region that is annually swept by sea ice, it provides an excellent opportunity to examine ice impacts on phytoplankton blooms and particle export, life histories of Antarctic krill, and recruitment successes of organisms at all trophic levels. Because of the nature and design of "long-term" studies, conclusive results from the Palmer LTER initiative are not expected for several years. However, in the context of this R/V Polar Duke farewell tribute, I think it is appropriate to emphasize the field demands and challenges that a program like this creates (including nearly 1 year of at-sea data collection to date), as well as the numerous program successes that were possible as a result of the hard work and expertise of the R/V Polar Duke crew and the shipboard ASA support staff.

\section{The R/V Polar Duke Legacy}

In this "farewell tribute" article I have tried to chronicle a few of the R/V Polar Duke's many significant contributions to the U.S. Antarctic Program. Of course, this otherwise excellent platform for oceanographic research would be nonfunctional if it were not for the untiring efforts of a skilled and efficient master and his crew. In the conduct of Antarctic field research, logistics 
planning and support are as vital as scientific expertise and protocol. The long list of important scientific accomplishments and extensive knowledge that was gained during the Duke's 13-yr watch will carry on as her living legacy. As new research programs are built upon this strong research foundation, we will reminisce about our past great adventures in the Southern Ocean. Just as many Antarctic veterans were disappointed when the R/V Hero was replaced by the R/V Polar Duke in 1984, many of us are sad to see the Duke retired. However, we should focus on the future and to the new science opportunities within USAP. The R/V Polar Duke has served our field programs with distinction, and for that we shall be eternally grateful. It is appropriate and in the full spirit of "science first" that even during her "deadhead" north to Louisiana, the R/V Polar Duke supported important research on the latitudinal effects of UV radiation on DNA damage in marine bacteria (W. Jeffrey, Chief Scientist). This final cruise, the "LAST I" (LAtitudinal Sampling Transect-I) is the swan song in her rich USAP legacy.

On behalf of the women and men of the U.S. Antarctic Program, the author would like to extend his sincere, heartfelt thanks to our Duke friends and colleagues for a job well done. They will be a hard act to follow, and we wish them fair seas and a safe journey en route to their next assignment.

\section{ACKNOWLEDGEMENTS:}

I thank Al Sutherland, Polly Penhale, Guy Guthridge, and Nadene Kennedy (all at NSF); Marian Moyher, Kip Rithner, and Steve Kottmeier (all at ASA); and Lisa Lum and Lance Fujieki (both at University of Hawaii) for their help on various aspects of this project, and I gratefully acknowledge all those who contributed stories and photos for the R/V Polar Duke web page. I also thank my mentor, Ozzie Holm-Hansen for providing me with an opportunity to first conduct research in Antarctica in 1976, and to the National Science Foundation's Office of Polar Programs for supporting my subsequent research efforts in the Southern Ocean. A special "aloha" goes out to bosun Agnor "Shorty" Hansen (Rieber) and to marine technician Cole Mather (ITT-ANS/ASA), who were both there from the start (1985) to the finish (1997). Finally, I gratefully acknowledge my graduate students, technical staff, and other colleagues who participated in my 20 Antarctic research expeditions conducted since 1985, and I especially thank the officers and crew of the R/V Polar Duke, ITTANS/ASA support personnel and Chilean maritime port agents for making it all happen.

\section{REFERENCES}

Ainley, D.G. and C.V. Sullivan, 1989: AMERIEZ 1988: a summary of a winter cruise of the Weddell and Scotia seas on Polar Duke. Antarct. J. U.S. 24, 144-145.

Ainley, D.G., W.R. Fraser, C.W. Sullivan, J.J. Torres, T.L. Hopkins and W.O. Smith, Jr., 1986: Antarctic mesopelagic micronekton: evidence from seabirds that pack ice affects community structure. Science, 232, 847-849.

Anonymous, 1968: Hero: a new Antarctic research ship. Antarct. J. U.S., 3, 53-61.

Bidigare, R.R., 1989: Potential effects of UV-B radiation on marine organisms of the Southern Ocean: distributions of phytoplankton and krill during austral spring. Photochem. Plotobiol., 50, 469-477.

Bird, D.F., R. Maranger and D.M. Karl, 1993: Palmer LTER: aquatic virus abundances near the Antarctic Peninsula. Antarct. J. U.S., 28, 234-235.

Booth, C.R., T.B. Lucas, J.H. Morrow, C.S. Weiler and P.A. Penhale, 1994: The United States National Science Foundation's polar network for monitoring ultraviolet radiation. In: Ultraziolet Radiation in AntarctionMeasurements and Biological Effects, vol. 62. C.S. Weiler and P.A. Penhale, eds. Antarctic Research Series, American Geophysical Union, Washington, D.C., 17-37.

Chisholm, S.W. and F.M.M. Morel eds., 1991: What controls phytoplankton production in nutrient-rich areas of the open sea? Limnol. Oceanogr., 36, 1507-1965.

Comiso, J.C. and C.W. Sullivan, 1986: Satellite microwave and in situ observations in the Weddell Sea ice cover and its marginal ice zone. J. Geophys. Res., 91, 9663-9681.

Farman, J.C., B.G. Gardiner and J.D. Shanklin, 1985: Large losses of total ozone in Antarctica reveal seasonal CIO./NO interaction. Nature, 315, 207-210.

Fraser, W.R. and D.G. Ainley, 1986: Ice edges and seabird occurrence in Antarctica. BioScience, 36, 258-263.

Frederick, J.E. and D. Lubin, 1994: Solar ultraviolet irradiance at Palmer Station, Antarctica. In: Ultraziolet Radiation in Antarctica: Measurcments and Biological Effects, vol. 62. C.S. Weiler and P.A. Penhale, eds. Antarctic Research Series, American Geophysical Union, Washington, D.C., 43-52.

Häder, D.P. and R.C. Worrest, 1991: Effects of enhanced solar ultraviolet radiation on aquatic ecosystems. Photochem. Photobiol, 53, 717-725.

Hedgpeth, J.W., 1977: The Antarctic marine ecosystem. In: Adaptations within Antarctic Ecosystems. G. Llano, ed., Proceedings of the Third SCAR Symposium on Antarctic Biology, Smithsonian Institution, Washington, D.C., 3-10.

Helbling, E.W., V. Villafañe, M. Ferrario and O. Holm-Hansen, 1992: Impact of natural ultraviolet radiation on rates of photosynthesis and on specific marine phytoplankton species. Mar. Ecol. Prog. Ser., 80, 89-100.

Helbling, E.W., V. Villafañe and O. Holm-Hansen, 1994: Effects of ultraviolet radiation on Antarctic marine phytoplankton photosynthesis with particular attention to the influence of $\mathrm{n}$-fixing. In: Ultraziolet Radiation in Antarction: Measurements and Biological Effects, vol. 62. C.S. Weiler and P.A. Penhale, eds., Antarctic Research Series, American Geophysical Union, Washington, D.C., 207-227.

Holm-Hansen, O., E.W. Helbling and D. Lubin, 1993: Ultraviolet radiation in Antarctica: inhibition of primary production. Photochem. Photobiol., 58, 567-570.

Holm-Hansen, O., B.G. Mitchell and M. Vernet, 1989: Ultraviolet radiation in antarctic waters: effect on rates of primary production. Antarct. J. U.S., 24, 177-178.

Huntley, M.E., D.M. Karl, P. Niiler and O. Holm-Hansen, 1991: Research on Antarctic Coastal Ecosystem Rates (RACER): an interdisciplinary field experiment. Decp-Sea Res., 38, 911-941.

Jiang,Y., Y.L. Yung and R.W. Zurek, 1996: Decadal evolution of the Antarctic ozone hole. I Geophy/s. Res., 101, 8985-8999. 
Jones, T.O., 1964: New U.S. research station in the Antarctic Peninsula. Nature, 204, 825-826.

Karentz, D., F.S. McEuen, M.C. Land and W.C. Dunlap, 1991: Survey of mycosporine-like amino acid compounds in Antarctic marine organisms: potential protection from ultraviolet exposure. Mar. Biol., 108, 157-166.

Karentz, D., M.L. Bothwell, R.B. Coffin, A. Hanson, G.J. Hemdl, S.S. Kilham, M.P. Lesser, M. Lindell, R.E. Moeller, D.P. Morris, PJ. Neale, R.W. Sanders, C.S. Weiler and R.G. Wetzel, 1994. Impact of UV-B radiation on pelagic freshwater ecosystems: report of working group on bacteria and phytoplankton. Archiv fur Hydrobiologie Beihefte Ergebnisse de Limnologie, 43, 31-69.

Karl, D.M., ed., 1991: RACER: Research on Antarctic Coastal Ecosystem Rates. Deep-Sea Res., vol. 38. Pergamon, New York.

Karl, D.M. and J. Resing, 1993: Palmer LTER: hydrogen peroxide in the Palmer LTER region. IV. Photochemical interactions with dissolved organic matter. Antarct. I. U.S., 28, 231-234.

Kennicutt, M.C., S.T. Sweet, W.L. Stockton, K. Dunton, L. Martin, D.M. Karl, L. Quetin, D. Laur, C.D. Amsier, R. Rowley, J. Campbell, B. Todd, P. Grecay, O.L. Palma, G. Ferrerya and V. Alder, 1990: Oil spillage in Antarctica. Environ. Sci. Tech., 24, 620-624.

Kieber, D.J., 1994: Photochemistry of Antarctic waters, during the 1993 austral spring. Antarct. J U.S., 29. 100-102.

Lansing, A., 1959: Endurance: Shackleton's Incredible Voyage. Carroll \& Graf Publishers, New York, $282 \mathrm{pp}$.

Lipps, J.H., 1976: The United States' "East Base," Antarctic Peninsula. Antarct. I. U.S., 11. 211-219.

Malloy, K.D., M.A. Holman, D. Mitchell and H.W. Detrich, 111, 1997: Solar UVB-induced DNA damage and photoenzymatic DNA repair in Antarctic zooplankton. Proc Natl. Acad. Sci. USA, 94, 1259-1263.

Martin, J.H., R.M. Gordon and S.E. Fitzwater, 1990: Iron in Antarctic waters. Nature, 345, 156-158.

Molina, M.J. and F.S. Rowland, 1974: Stratospheric sink for chlorofluoromethanes: chlorine atom-catalysed destruction of ozone. Nature, 249, 810-812.

Parfit, M., 1986: A new ship tests the rigor of winter in the Antarctic. Smithsonian, 17, 117-12T

Prézelin, B.B., N.P. Boucher and R.C. Smith, 1994: Marine primary production under the influence of the Antarctic ozone hole: Icecolors '90. In: Ultraviolet Radiation in Antarctica: Measurements and Biological Effects, vol. 62. C.S. Weiler and P.A. Penhale, eds. Antarctic Research Series, American Geophysical Union, Washington, D.C., 159-186.
Ross, R.M., E.E. Hofmann and L.B. Quetin, 1996: Foundations for Ecological Research West of the Antarctic Peninsula, vol. 70. Antarctic Research Series, American Geophysical Union, Washington, D.C., 448 pp.

Schnell, R.C., S.C. Liu, S.J. Oltmans, R.S. Stone, D.J. Hofmann, E.G. Dutton, T. Deshier, W.T. Sturges, J.W. Harder, S.D. Sewell, M. Trainer and J.M. Harris, 1991: Decrease of summer tropospheric ozone concentrations in Antarctica. Nature, 351, 726-729

Smith, R.C., B.B. Prézelin, K.S. Baker, R.R. Bidigare, N.P. Boucher, T. Coley, D.Karentz, S. MacIntyre, H.A. Matlick, D. Menzies, M. Ondrusek, Z, Wan and K. J. Waters, 1991: Ozone depletion: ultraviolet radiation and phytoplankton biology in Antarctic waters. Science, 255, 952-959.

Smith, R.C., K.S. Baker, W.R. Fraser, E.E. Hofmann, D.M. Karl, J.M. Klinck, L.B. Quetin, B.B. Prézelin, R.M. Ross, W.Z. Trivelpiece and M. Vemet, 1995: The Palmer LTER: a longterm ecological research program at Palmer Station, Antarctica. Oceanogr. Mag., 8, 77-86.

Smith, W.O., Jr. and D.L. Garrison, 1990: Marine ecosystem research at the Weddell Sea ice edge: the AMERIEZ program. Oceanogr. Mag., 3, 22-29.

Solomon, S., R.R. Garcia, F.S. Rowland and D.J. Wuebbles, 1986: On the depletion of Antarctic ozone. Nature, 321, 755-75.

Steele, J.H., 1981: An Evaluation of Antarctic Marine Ecosystem Research. National Academy Press, Washington D.C., 99 pp.

Sullivan, C.W. and D.G, Ainley, 1987: Antarctic marine ecosystem research at the ice-edge zone, 1986. Antarct. J. US., 22, 167-169.

Sullivan, C.W., C.R. McClain, J.C. Comiso and W.O. Smith, Jr., 1988: Phytoplankton standing crops within an Antarctic ice edge assessed by satellite remote sensing. J. Geophys. Res., 93,12487-12498.

Villafañe, V.E., E.W. Helbling, O. Holm-Hansen and B.E. Chalker, 1995: Acclimatization of Antarctic natural phytoplankton assemblages when exposed to solar ultraviolet radiation. J. Plankton Res., 17, 2295-2306.

Voytek, M.A., 1990: Addressing the biological effects of decreased ozone on the Antarctic environment. Ambio, 19, 52-61. 